Article

\title{
Expansion of Commercial Sugarcane Cultivation among Smallholder Farmers in Uganda: Implications for Household Food Security
}

\author{
Edward N. Mwavu ${ }^{1, *}$, Vettes K. Kalema ${ }^{2}$, Fred Bateganya ${ }^{3}$, Patrick Byakagaba ${ }^{1}$, \\ Daniel Waiswa ${ }^{1}$, Thomas Enuru ${ }^{1}$ and Michael S. Mbogga ${ }^{1}$ \\ 1 School of Forestry, Environmental and Geographical Sciences, Makerere University, P.O. Box 7062, Kampala \\ Uganda; Byakagaba@caes.mak.ac.ug (P.B.); daniel.waiswa@gmail.com (D.W.); tenuru@caes.mak.ac.ug (T.E.); \\ mbogga@caes.mak.ac.ug (M.S.M.) \\ 2 Kachwekano Zonal Agricultural Research and Development Institute, P.O. Box 421, Kabale, Uganda; \\ vetteskalema@gmail.com \\ 3 College of Humanities and Social Sciences, Makerere University, P.O. Box 7062, Kampala, Uganda; \\ frebat2011@gmail.com \\ * Correspondence: emwavu@caes.mak.ac.ug or edward.mwavu@gmail.com; Tel.: +256-772-510-831
}

Received: 31 January 2018; Accepted: 5 June 2018; Published: 11 June 2018

\begin{abstract}
Understanding the impact of commercial agriculture in the face of global change is critical to support strategies that ensure food security and alleviate poverty among households. We assessed the contribution of commercial sugarcane cultivation to household-level food security among smallholder farmers in Busoga sub-region, eastern Uganda. Land use changes are motivated by quick commercial gains rather than sustained food production; a situation that influences food security. The majority of households cultivate few crop varieties, lack adequate and nutritious foods, and have inadequate income to purchase food to meet their needs. Inadequacy of food within some commercial sugarcane-cultivating households suggests that generating income does not necessarily increase food security. To cope with food insecurity, households offer labour in exchange for food, borrow food, ration food, and at times steal. This is exacerbated by increasing food crop failures, large family sizes, trade in food items, and declining availability of food and land for food production. Commercial sugarcane cultivation is the main driver of food insecurity but given its perceived economic benefits, future sugarcane plantations expansion in the region is probably inevitable. Therefore, future policy should be designed to provide triple-win strategies (i.e., food security, poverty alleviation, and climate change adaptation) that provide sustainable livelihoods.
\end{abstract}

Keywords: poverty alleviation; sustainable livelihoods; climate change; commercial agriculture

\section{Introduction}

Understanding the impact of commercial agriculture in the face of increasing human population and climate change in a rural landscape is critical for biodiversity sustainability and meeting the needs of households whose livelihoods (i.e., food, medicine, and income) are mainly dependent on natural resources. In many sub-Saharan African countries, subsistence agriculture (i.e., crop, tree, livestock, and fisheries production) is not only a vital source of food but also the prevalent way of life. However, in these countries with mainly agrarian economies, subsistence agriculture is increasingly being replaced by commercial agriculture as national governments push to increase the contribution of the agriculture sector to the national Gross Domestic Product (GDP) [1-3]. By 2016, the contribution of the agricultural sector ranged between 3\% (for Botswana and South Africa) and more than 50\% (for Chad) [3]. For Uganda, the contribution of the agriculture to the GDP was about 
$25.8 \%$ [4]. With increasing interest in agriculture as an income earner, commercial firms and households in tropical Africa and Asia countries have adopted commercial agriculture leading to expansive lands of monocultures (incl. oil palms, sugarcane, tobacco, and sunflower) in historically forested and subsistence-oriented agriculture production systems, but with mixed results. For sub-Saharan Africa, the total value of agricultural output has grown markedly over the past decade; however, it remains the most food insecure region in the world [3]. According to Binswanger \& von Braun [5], the optimistic view is that normally, technology and commercialization stimulates agricultural growth, improves employment opportunities, and expands food supply that are all central to the alleviation of poverty. In the tropical Asian countries (e.g., Malaysia, Indonesia, Sumatra, and Papua New Guinea), oil palm cultivation is reported to be profitable, offering wealth and development, but it also threatens traditional livelihoods and biodiversity [6-10].

In Uganda, recent times have witnessed the central government encouraging farmers to invest in commercial agricultural enterprises as one of the efforts for poverty alleviation and wealth creation. In areas close to sugarcane-processing industries in Uganda (e.g., Kinyara Sugar Works Ltd., Masindi, Mayuge Sugar Ltd., Mayuge, Kaliro Sugar Ltd., Kaliro, and Kakira Sugar Works Ltd., Jinja), sugarcane cultivation has been highly preferred relative to other more traditional crops (e.g., coffee, cotton) as well as plantation forests, as it is perceived to be more profitable and economically valuable [11]. As commercialization of sugarcane and other non-food crops cultivation increases in importance to rural households, the value of productive land and incentives to increase yields continue to escalate, resulting in further loss of natural vegetation, and a reduction of land available for food crop cultivation [12]. This reduction of land for food crops is of major concern, as producing more food for a growing population in the coming decades, while at the same time combating poverty and hunger and coping with the impacts of climate change is the major challenge facing agriculture in Africa. It is important to note that food production is dependent among other factors on environmental (including large-scale changes in land use, biogeochemical cycles, climate and biodiversity) and economic conditions $[13,14]$. This might also have crucial consequences for food security and nutrition for rural populations, where high human population growth and poverty reduction are of great concern. In Uganda, like in many African countries, food insecurity amongst poor households remains a serious problem, contributing to poor health, problems with learning in school, and lack of socio-economic development [15]. Indeed, regional and seasonal food insecurity and varying degrees of malnutrition within the general population are among the development challenges faced by Uganda [3]. Food security may be defined as a situation that exists when all people always have physical, social and economic access to sufficient, safe and nutritious, and is acceptable within the given culture food to meet dietary needs and food preferences for an active and healthy life [13,16-18]. It also includes obtaining foods without resorting to emergency food supplies, scavenging, stealing, or similar coping strategies [17].

Some studies (e.g., $[19,20]$ ) elsewhere suggest that commercial agriculture, especially oil palm and sugarcane growing, increases household income, thus indirectly addressing food security. Other studies (e.g., $[9,10,21])$, however, have found that cash cropping undermines food and livelihood security particularly for smallholder farmers. In spite of the increased commercial sugarcane cultivation in various regions of Uganda ostensibly resulting in improved household incomes and road infrastructure, its impacts on rural household food security are not clearly known. Yet a clear understanding of the area-specific factors that influence household-level food security and nutrition in rural commercial agricultural landscapes is fundamental if we are to achieve food security. Such an understanding may support strategies/policies for ensuring food security among households as they practice commercial agriculture to alleviate poverty. The fight to eliminate hunger at the household level and reach the other UN Sustainable Development Goals (SDGs) targets in sub-Saharan Africa will be won or lost in the rural areas where most the poor and hungry people live.

In this study, we assessed the contribution of commercial sugarcane cultivation to household-level food security within the commercial sugarcane cultivation landscape of Mayuge and Jinja Districts, 
in Busoga sub-region, Eastern Uganda. In this regard, we attempted to address the following questions: (i) does engaging in commercial sugarcane growing increase or undermine household-level food security; (ii) what are the levels of food security, food insecurity, and hunger among the households in the sugarcane cultivating villages; (iii) apart from sugarcane cultivation, what other social-economic activities do households participate in; and lastly (iv) wat strategies do households use to cope with food insecurity? We also sought to understand the changes in land-use/cover types over a decade (i.e., between 2000 and 2016) with major interest in commercial sugarcane plantations coverage.

\section{Materials and Methods}

\subsection{Description of the Study Area}

The study was conducted in the sugarcane out-grower villages of Jinja and Mayuge Districts within a radius of $21 \mathrm{~km}$ from the Kakira Sugar Works Limited (KSWL) factory, Jinja, Uganda (Figure 1). This is an area where most of the registered out-growers for KSWL are located and therefore areas of small and large-scale commercial sugarcane cultivation. Agriculture is the main land use activity and source of income for the local population in most parts of Jinja and Mayuge Districts. With the falling prices for cotton and coffee in these districts, commercial sugarcane growing is increasing in importance as a cash crop. However, recent vulnerability assessment indicates that changes in climate will alter crop phenology, as well as increasing the incidence of crop pests and diseases, especially because of higher temperatures [22]. Climate projections for most of Uganda also indicate higher temperatures-about $5 \%$ increase in precipitation in most areas, with increasing spatial and season variability.

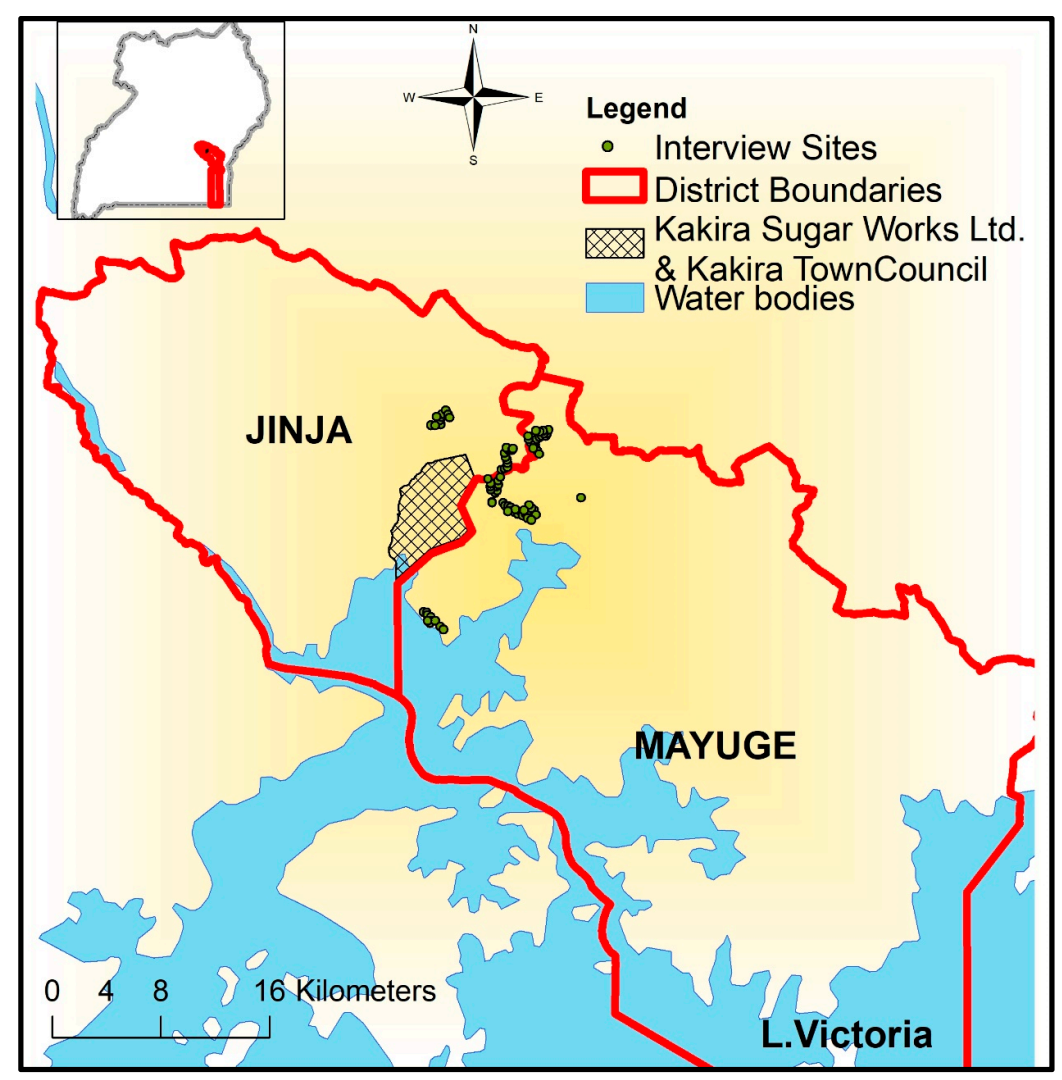

Figure 1. A location map of the study area showing the 120 interview sites ( $(\bullet)$ within a radius of 21 $\mathrm{km}$ from Kakira Sugar Works Limited, Jinja in the commercial sugarcane growing villages of Jinja and Mayuge District, Eastern Uganda. 


\subsection{Methods}

\subsubsection{Study Design and Data Collection}

The study applied an exploratory research design in which face-to-face questionnaire interviews with households/respondents were applied in data collection. Households/respondents were randomly selected from 10 villages, each village contributing at least 10 households. The ten villages were derived from a population of 89 villages based on a sample size calculation using a 95\% confidence level and a 20\% Margin of Error. To be eligible for the study, a household had to have at least one adult resident who grows sugarcane or has lived in the area for more than 10 years but not necessarily growing sugarcanes. The questionnaire interviews were conducted on an individual basis to minimize peer influence [23]. In total 208 respondents were interviewed. The questions covered in the questionnaire focused on: (i) general household characteristics such as gender, age group, ownership of land, level of education and main source; (ii) household incomes; (iii) organization membership; (iv) crops cultivated for cash income and food; (v) decision making on crops planted; (vi) adequacy of food provisioning; (vii) observed trends in food production and availability; and (viii) quality and variety of food available to households. In addition, time series Landsat imagery (2003 and 2016) were obtained from United State Geological Surveys (USGS) database to aid in assessing the changes in sugarcane coverage in the study area.

\subsubsection{Data Analysis}

Quantitative data was entered into an Epi Info database and exported to an SPSS dataset for analysis. Themes related to the study objectives were identified and formed the codes to be used in the analysis. Data were analysed using descriptive and inferential statistics generated in SPSS 17.0 [24]. Summary statistics, for example the mean, frequency, percentages, and totals were generated to show the number of households, which responded to each variable of interest. The relationship between dependent variable (i.e., vulnerability to food insecurity) and the independent variables (i.e., socio-economic and demographic characteristics of households among other categorical variables) was determined using a Pearson's Chi-square $\left(\chi^{2}\right)$ statistics at $5 \%$ level of significance. The time series Landsat imagery (2003 and 2016) were subjected to image pre-processing and supervised classification procedures in ENVI software to determine the changes in sugarcane coverage in the study area over the time.

\section{Results}

\subsection{Description of Respondents}

The majority $(72.6 \%)$ of respondents were males (Table 1$)$, which is not surprising, given that in the study area the patriarchy social system dominates. This has implications for the ownership of/or access to productive assets in the agriculture sector amongst other economic activities. The decisions on what type of plants/crops to be cultivated on the land and the acreage to be cultivated for a crop, even for the type of food security crops, is mainly made by males. This is likely to negatively affect household food security since males are mainly interested in crops that earning money. It was also observed that a majority (91\%) of the respondents were below the age of 60 years, and most (59.3\%) of them were members to sugarcane out-growers' group. This suggests that they have a high interest in sugarcane cultivation and a need to organize themselves for better outcomes. Over $78 \%$ of the respondents were smallholder farmers, and for most $(78.4 \%)$ of them, it was their major source of income. Very few households earn their income from salaries/wages (6.7\%) and trade (9.1\%). This dependence on smallholder agriculture that is rain-fed for food and income makes them more vulnerable to impacts of climate variability and change. The majority $(73.5 \%)$ of the households reported their annual income to be not more than USD275, which may on average be less than USD 1 per day. Although $54.8 \%$ of the households reported to rear livestock, they mostly owned one or two goats or cows. 
And those who kept it, did it mainly for trade (66.4\%), breeding (17.7\%), and consumption $(13.3 \%)$ among other reasons.

As for education, $84.5 \%$ of the respondents had attained at least some level of education (Table 1). Of these, $51.2 \%$ attained primary education and $31.9 \%$ had advanced to secondary school level education. However, the percentage of those who had advanced beyond secondary school level (i.e., university, tertiary, institute etc.) was relatively low, and they had also not gained training in any other specialties (e.g., agriculture). The household heads' low educational attainment and their lack of training in other specialties narrows their possibility of depending on other sources of livelihoods that requires higher education qualification, hence keeping them majorly in subsistence rain-fed agriculture.

Table 1. General household characteristics based on results from questionnaire interviews with respondents $(n=208)$ from Mayuge and Jinja Districts. 1USD = 3640UGX (Uganda Shillings).

\begin{tabular}{|c|c|}
\hline Household/Respondent Characteristics & Percentage Respondents \\
\hline \multicolumn{2}{|l|}{ 1. Gender } \\
\hline Female & 72.6 \\
\hline Male & 27.4 \\
\hline \multicolumn{2}{|l|}{ 2. Age group } \\
\hline$\leq 20$ & 4.2 \\
\hline $21-40$ & 45.0 \\
\hline $41-60$ & 41.8 \\
\hline 61 and above & 9.0 \\
\hline \multicolumn{2}{|l|}{ 3. Level of Education } \\
\hline None & 15.5 \\
\hline Primary Incomplete & 33.8 \\
\hline Primary Completed & 17.4 \\
\hline Secondary (Lower) & 30.0 \\
\hline Secondary (Upper) & 1.9 \\
\hline Post-Secondary & 1.4 \\
\hline \multicolumn{2}{|l|}{ 4. Membership to sugarcane out-growers' group } \\
\hline Household head is a Member & 59.3 \\
\hline Household head is a Non-Member & 40.7 \\
\hline \multicolumn{2}{|l|}{ 5. Occupation of household head } \\
\hline Smallholder Farmer & 78.8 \\
\hline Trader/Business Man/Woman & 7.7 \\
\hline Salary/Wage Earner & 5.3 \\
\hline Fishing & 2.9 \\
\hline None & 0.5 \\
\hline Other & 4.8 \\
\hline \multicolumn{2}{|l|}{ 6. Main source of income } \\
\hline Smallholder Farming & 78.4 \\
\hline Trade & 9.1 \\
\hline Salary/Wages & 6.7 \\
\hline Fishing & 1.4 \\
\hline Other & 4.3 \\
\hline \multicolumn{2}{|l|}{ 7. Mean annual household income (USD) } \\
\hline$<27.5$ & 14.5 \\
\hline $27.6-137.4$ & 31.9 \\
\hline $137.5-275$ & 27.1 \\
\hline$>275$ & 26.6 \\
\hline
\end{tabular}




\subsection{Dynamics of Sugarcane Plantation Coverage in Mayuge District}

Commercial sugarcane covered an area of 14,995 hectares in 2003 and 53,518 hectares in 2016 (Figure 2). This shows an increase in commercial sugarcane plantation coverage by $256.9 \%$ between 2003 and 2016. The land taken up for sugarcane growing replaces other land use/cover types and arable land, which includes land previously used for food crop cultivation, wetlands, forests and grasslands, as this was majorly a subsistence agriculture landscape.

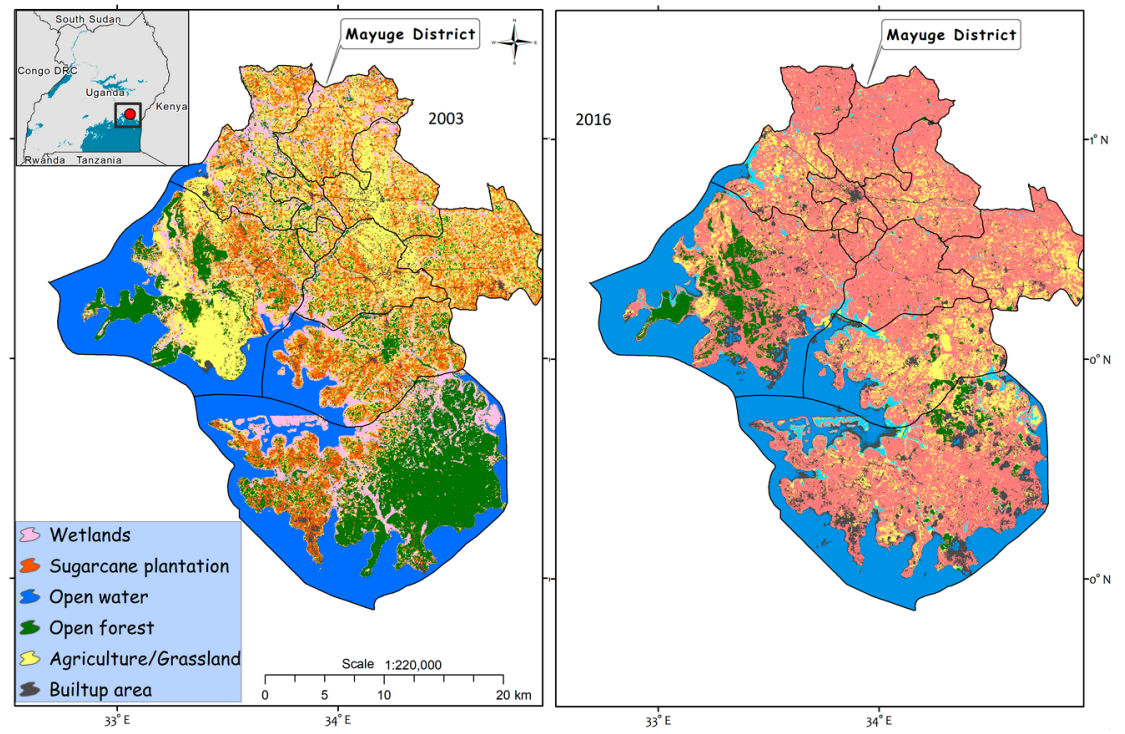

Figure 2. Land use/cover changes in Mayuge District between 2003 and 2016.

\subsection{Food Security, Insecurity and Hunger among Households}

Most (87\%) of the respondents (181 out of 208) reported that most of the households in Mayuge (95 out of 110) and Jinja (86 out 98) districts did not have adequate and nutritious food to meet their family needs in the last 12 months prior to the study. Among the respondents, there were sugarcane cultivators and those who were not but had rented out their land to other individuals for sugarcane cultivation Even among the commercial sugarcane cultivators, only 3 in every 10 households reported having access to adequate food. This is further compounded by the fact that there are few varieties of food crops cultivated by households, and the households do not have enough money to supplement what they grow.

Households were also found to not always have enough food and of the quality and/or variety needed to eat, with households with large family sizes and children the most vulnerable. The major reasons for this situation were low household financial capacity (92.4\%), limited arable land available for food crop cultivation $(89.4 \%)$, poor farming practices and unreliable weather conditions resulting in low crop yields (88.3\%), and pest and diseases damage to food crops (87.1\%) (Figure 3). In spite of a lack of enough food to eat, some households go ahead and sell the little food harvested to earn an income for use in meeting other household needs. To these families, food crops also serve as a short-term source of income, yet usually the food harvests are very low. Food crops usually take a short time to mature, while the maturity cycle for major sugarcane varieties in the tropics is 12-20 months [25]. In the study area, households that participated in the study were found not to have the right quality or variety of food they need. This is majorly attributed to households having few varieties of food crops cultivated in their usually small home gardens and a lack of enough money to purchase food to supplement what they grow (Figure 3). The commonly grown crops and are the major sources of food for every household are maize (Zea mays L.), cassava (Manihot esculenta Crantz.), sweet potaoes (Ipomea batatas (L.) Lam), and beans (Phaseolus vulgaris L.). These are mainly starchy foods, while most of the 
previously cultivated nutritious foods like cowpeas, Bambara nuts, soya beans, and simsim have been lost from agricultural systems. Poor farming practices, low soil fertility, and pests and diseases inhibit proper cultivation, as most of the crops are sensitive to such conditions, limiting farmers to a few varieties that are resilient. Other reasons for households not always having the right quality or variety of food they want include lack of enough time for cooking, absence of quality foods in the nearby local shops, and not enough firewood for cooking. Indeed, most of the traditional sources of fuelwood (e.g., forests, and woodlands) have been replaced by sugarcane plantations, making it difficult to get fuelwood to cook the three meals required in a day; foods like beans require a lot of biomass energy.

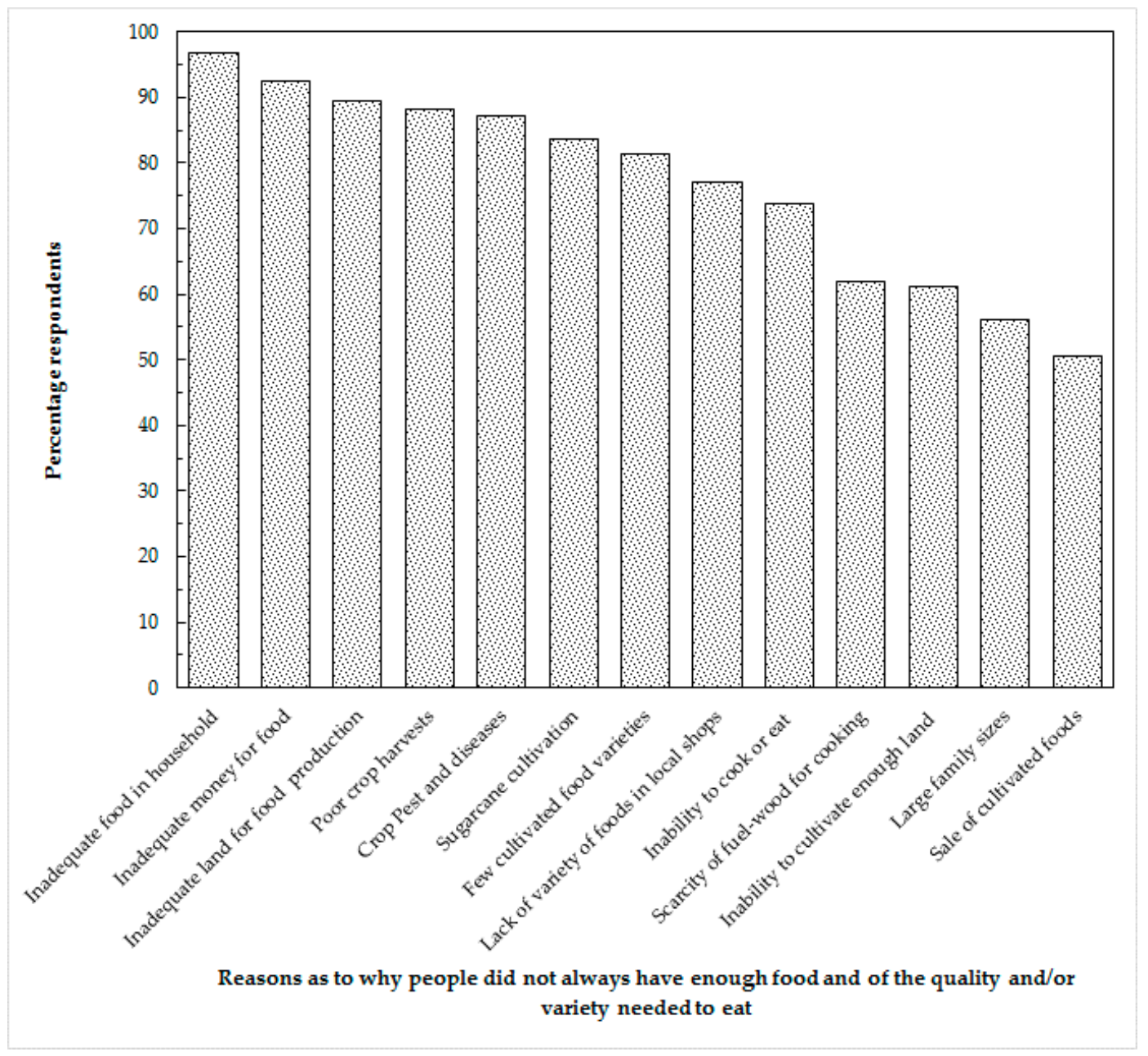

Figure 3. Reasons cited as to why people did not always have enough food and of the quality and/or variety to eat in the surveyed households in areas of commercial sugarcane cultivation of Mayuge and Jinja Districts, Eastern Uganda $(n=208)$.

These results point to a food insecurity situation within the commercial sugarcane cultivation areas. The main causes of this food insecurity situation were reported to also include sugarcane cultivation, poor soils, poor farming practices, sale of all food harvests, and prevalence of crop pest and diseases (Figure 3). Nearly 21 in every 25 households (i.e., 84\%) reported commercial sugarcane cultivation as the main source of food insecurity in the area. Furthermore, out of the 64 households that were engaged in commercial sugarcane cultivation, most of them $(78.1 \%)$ cited sugarcane cultivation as the main cause of food insecurity in the community.

Faced with the challenge of food insecurity, households employ various coping strategies that include offering labor in exchange for food (30.8\%), borrowing food $(9.1 \%)$, rationing of food $(7.2 \%)$, 
and at times stealing from their neighbors. This food insecurity situation in the study area has been exacerbated by increasing trends in crop failures, family sizes, trade in food items in the villages (Figure 3), as well as declining food availability, land available for crop cultivation, and livestock numbers (Figure 4).

\subsection{Perceived Trends in Relation to Food Production and Availability}

In the 5-10 years prior to the study, a decrease in land availability for crop cultivation, food availability and livestock numbers (Figure 4) was observed. The declining land availability result here corroborates the results of the land use/cover change analysis results (Figure 2) that show that increasing land for sugarcane cultivation has over the years taken over the arable for food crop production and other natural ecosystems. On the other hand, family sizes, trade in food, and food crop failures are reported to have increased. The combination of increased food crop failures, family sizes, and the decreased land available for food crop cultivation heightens the food insecurity situation in the study area. Most of the households now depend on their home gardens as the main source of food and nutrition. However, the sizes of these home gardens continue to shrink as some of them, and where they are located, is increasingly converted into the assumedly lucrative commercial sugarcane plantations.

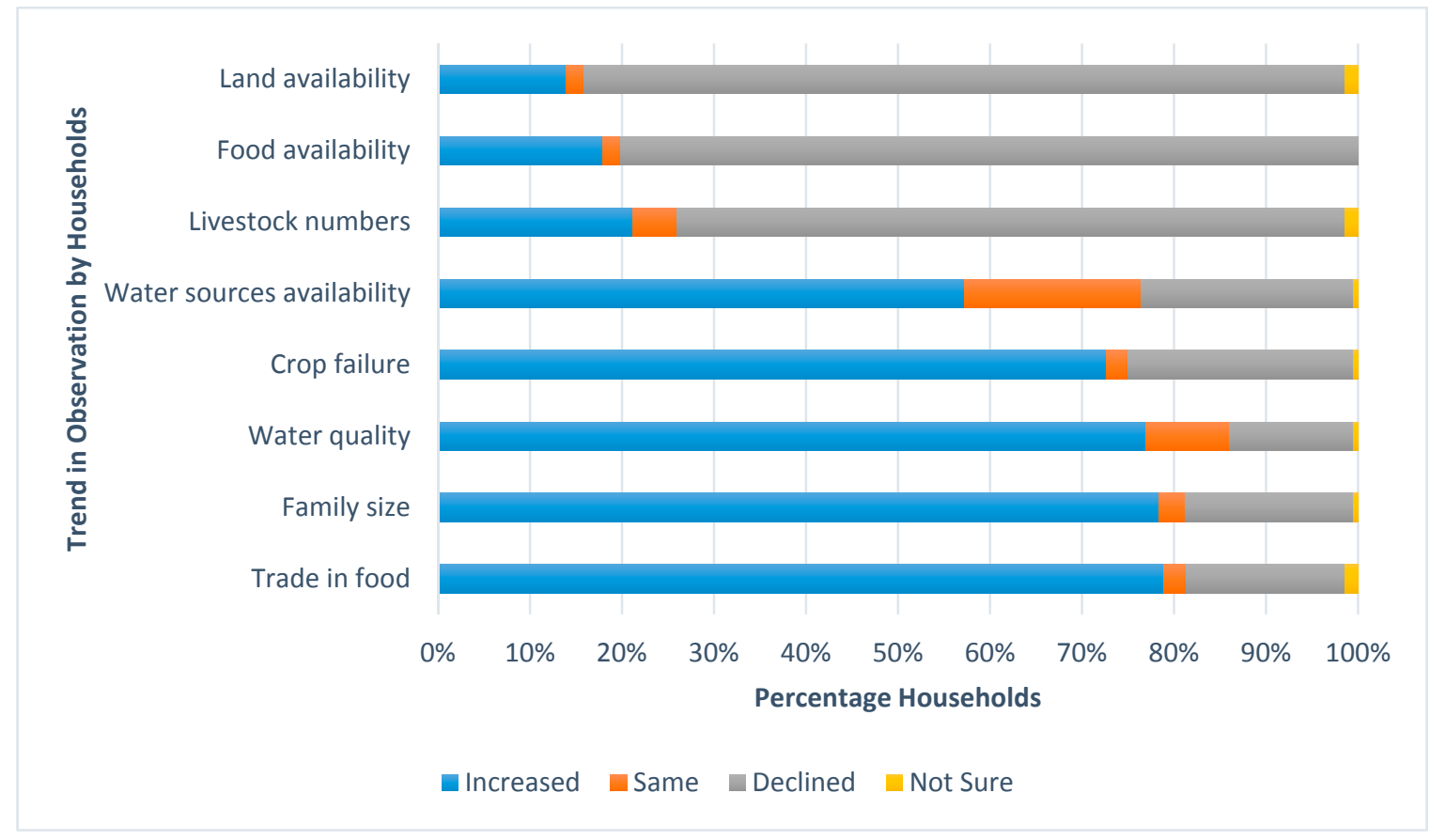

Figure 4. Perceived trends observed in 5-10 years prior to the study year in relation to food production and availability in the commercial sugarcane cultivation areas of Mayuge and Jinja Districts, Eastern Uganda.

\subsection{Relationship between Household Characteristics and Likelihood of Being Food Insecure}

Our results reveal that there is a relationship between household characteristics and their likelihood of being food insecure. Most (i.e., $62.5 \%$ ) of the male-headed households and those (68.0\%) that owned land were found to be the most food insecure. Food insecurity among the households was significantly related to status of access to land $\left(\chi^{2}=4.8, \mathrm{df}=1, p=0.028\right)$, land size owned $\left(\chi^{2}=10.75, \mathrm{df}=3, p=0.013\right)$, and size of land under sugarcane cultivation $\left(\chi^{2}=4.72, \mathrm{df}=1, p=0.03\right)$ (Table 2). This suggests that households with more land under sugarcane cultivation are more likely to have less land under food crop cultivation and therefore more food insecure. Hence, the gender of the 
household head and land variables appear to be a key factor in the food security puzzle in the study area. Some of the households with land lease it out for a period of eight years to other individuals with the capacity to cultivate sugarcanes on a commercial scale, leaving them with very small or no land at all to cultivate food crops. Meanwhile, those who cultivate sugarcanes do not always have enough money to sustain them through an 18-month period when the sugarcanes can be mature enough to be harvested and marketed. Yet, many of the sugarcane cultivators do not have multiple plantations of different ages to ensure that they will always have one to harvest throughout the year.

Table 2. Relationship between household characteristics and their likelihood of being food insecure $(n=208)$.

\begin{tabular}{ccc}
\hline Household Characteristic & \multicolumn{2}{c}{ Food Insecure } \\
\cline { 2 - 3 } & No. of HH (\%) & $\chi^{2}, \mathbf{d f}, p$ \\
\hline Gender & - & \\
Level of education of household head & - & \\
Main occupation of household head & $143(68.8)$ & \\
Participate in farmer groups & $52(35.3)$ & $4.8,1,0.028$ \\
Decision making & - & $10.75,3,0.013$ \\
Status of access to land & - & $4.72,1,0.03$ \\
Land size & - & $9.11,4,0.058$ \\
Land under sugarcane cultivation & - & \\
Land under food crop cultivation & \multicolumn{2}{l}{}
\end{tabular}

No. of $\mathrm{HH}(\%)=$ Number of households (Percentage).

\section{Discussion}

\subsection{Food Security Situation and Coping Strategies among Households}

The three interrelated elements that are essential to achieving food security in each community are food availability (sufficient quantities available for consumption), food access (adequate resources to obtain appropriate foods for a nutritious diet), and food utilization (a diet providing sufficient energy and essential nutrients $[11,26]$. Results of the present study reveal that the people in this commercial sugarcane growing region are food insecure, as they do not always have both the physical and economic access to sufficient food to meet their dietary needs for a productive and healthy life $[13,26,27]$. In their study in the same region Mwavu et al. [12] found that a majority of the households rely on subsistence crop agriculture and agrobiodiversity of home gardens as their main source of food and income. Similarly, for most of oil palm smallholders in Papua New Guinea, living on land settlement schemes, garden food production, whether for domestic consumption or for sale at local markets, is a fundamental component of their livelihood strategies [10]. However, the home gardens in the Busoga sub-region are also increasingly experiencing the loss of important and nutritious food crops like cowpeas, soya beans, aerial yams, and Bambara groundnuts [12] from agricultural systems. Thus, in the study area, subsistence food crop agriculture is increasingly under threat, yet according to research by Baiphethi \& Jacobs [28] it can play an important role in reducing the vulnerability of rural and urban food insecure households and improving livelihoods.

Some of the households in the present study had to cope with food insecurity by resorting to offering labor in exchange for food, borrowing food, rationing of food, and at times stealing from their neighbors. However, to be food secure, households must obtain food without resorting to emergency food supplies, scavenging, stealing, or similar coping strategies to meet their dietary needs and food preferences for an active healthy life [17]. In this area, children are the most likely to be affected by food shortage in the household and the community. Similarly, among the migrant and seasonal Latino farmworkers, households with children were reported to have a significantly higher prevalence of food insecurity than those without children [29]. 
Male-headed households and those with very small land areas under food crop cultivation were found to be the most food insecure, although they are assumed to have high income than women. This is not surprising given the evidence from other parts of Africa (e.g., Rwanda), Asia, Latin America, which has shown that women's income has greater positive effect on food security than men's income [30]. This was not expected, considering that owning land would give one an opportunity to grow food crops. But most land owners who are mostly men utilize their land for sugarcane production or rent it out to other individuals with the cash to cultivate sugarcanes, thus reducing arable land for food production. In the present circumstances in the study area, of reduced land available for food crop, there is also increasingly little opportunity to implement improved agroforestry systems, yet they have the potential to reduce the vulnerability of smallholder farmers and help them adapt to changing conditions [31]. One of the adaptation options of the food cropping system in the study area would be to alter the timing and location of the cropping activities [32]. However, this is also increasingly becoming hard since most of the households do not have alternative land for relocation or fallowing. Furthermore, households lack diversified incomes with little or no integration with other farming activities such as livestock rearing given the lack of land for agro-pastoral livestock systems.

\subsection{Commercial Agriculture and Its Implications for Food Security among Households}

While largescale commercial agriculture has succeeded in feeding the world, it has in the process also contributed to deforestation, loss of wetlands, soil erosion, biodiversity losses, and increased carbon emissions in many countries [9,33]. The expansion of sugarcane plantations is cited as presently the major source of food insecurity in the Busoga sub-region. Similarly, in Swaziland, sugarcane out-growers particularly the poorer ones were unable to meet their food requirements after converting all their land to rain-fed sugarcane [34]. The widespread conversion of wetland, forest, and arable crop land areas, leading to a commercial sugarcane plantation land matrix in the Busoga sub-region, is resulting in the loss of biodiversity; yet, biodiversity is fundamental to agricultural production and food security $[12,35]$. Loss of forest in the area has serious implications for household food security, since forests represent an important repository of food and other resources that can play a key role in contributing to food security, especially if integrated into complex systems that are managed for multiple benefits [36]. Moreover, these land-use/cover changes are driven largely by the increasing demand for more land to alleviate poverty and enhance the human and social welfare at household and community levels [37], and not necessarily food security. Given their limited alternative sources of income, smallholder farmers in these rural areas are often more involved in the cultivation of crops that can earn them an income than just food. Yet, the income from sugarcane cultivation comes once every 18 months, the average time required for sugarcane to reach a marketable age or maturity. Thus, this often compromises the sustainable management of their agro-diversity as well as food production, consequently exposing them to food insecurity and malnutrition. Expansion of commercial sugarcane cultivation is making it hard for these households to maintain an intact and interconnected ecosystem-one that will help them adjust to changing environmental conditions and continue to provide services [38], thereby reducing vulnerability to the impacts of climate change.

In the study area, the landscape is increasingly being fragmented with sugarcane plantations forming the land matrix. This is resulting in the loss of natural resources (incl. forests, wetlands and grazing lands), that are linked to household livelihood security and are also underlying factors for vulnerability to both climatic and non-climatic impacts [39]. The forest and wetland ecosystems that are being lost have been reported to play an important role in adaptation to the impact of climate change [40]. They are considered as "safety-nets", in that people draw on available natural resources to meet emergency shortfalls and to keep them from being worse off in times of need [41,42], particularly when agricultural crops fail because of climatic events [30]. The systematic loss of wetlands and natural forest patches in these rural areas is driving the already poor natural resources dependent households into deeper poverty, food insecurity, and malnutrition. Our findings corroborate the findings of the report of the National Household Survey 2016/2017 [43], where about $42.1 \%$ of the population in this 
region live below the poverty line. Although sugarcane cultivation is increasing income, it is only for a small percentage of households that are out-growers, and not the majority who just lease out their land for an eight-year period with a one-time pay off. For the lessor, the income is usually small and is spent within a short period of time to solve immediate household needs (e.g., pay school fees for children, medical bills, clothing, etc.); yet, they do not have any other consistent source of income. Moreover, the cycle of hunger in Uganda, like in any other sub-Saharan African country, begins and ends with poverty-the inability to grow or purchase food causes malnutrition and poor health, which in turn leads to the inability to earn income and deeper poverty. The poverty levels pose a major threat to household food security, since income is a critical determinant of a household's ability to obtain food [30], particularly in absence of sustainable own-production of quality food. Furthermore, given that these smallholder farmers often depend on local and their own rain-fed agricultural production, climate change will have negative effects on the food systems [44], reducing their access to adequate food. Projected changes in climate point to increasing moisture stress especially during the growing season, which calls for agriculture to rely on other ecosystem services like from forests or wetlands to remain resilient. A recent vulnerability assessment conducted in Uganda suggests that changes in climate will alter crop phenology, as well as increase the incidence of crop pests and diseases, especially because of higher temperatures [22].

\subsection{Perceived Trends in Food Inadequacy and Its Causes}

Most of the respondents indicated that they did not have adequate food, both in quantity and quality. This was mainly due to low incomes and limited arable land for crop production. Apart from smallholder agriculture- their main source of food and income-many households lacked other viable employment and economic activities to build their financial base to meet their livelihood needs. The sugarcane cultivation is an 18-month cycle, meaning that an individual or household with one plantation will have to wait for that period before gaining income; yet, they will be various household needs to meet. Thus, such a household will borrow in anticipation that it will refund when it sells its sugarcane produce. Hence, by the time such an individual sells the sugarcane, the income will have already been spent keeping him/her financially constrained. Further, according to a U.S. policy, food insecurity and hunger results from financial constraints and not voluntary restrictions in food intake [29]. Similarly, in our study, lack of money (i.e., financial constraint) to buy food to supplement what households grow is reported as one of the reasons why people do not always have the right quality or variety of food they need. Trend analysis also revealed that food and land availability, and livestock numbers had reduced in the last 10 years. This confirms other studies (e.g., [45]) that have found that commercial agriculture of non-food crops can negatively affect food security. It should also be noted that households' vulnerability to climate change impacts and food insecurity tends to increase as cash crops displace the traditional safety nets (e.g., forests) [41] and food crops in the farming systems, and household consumption of own-produced staple foods is reduced [46]. This is unlike a research by Kennedy \& Cogill [47] who reported that household food security is not jeopardized by commercial sugarcane growing. Indeed, sugarcane is a crop associated with significant positive and/or negative environmental and socio-economic impacts. It has been argued that moving up from the individual out-growers level and their households there are trade-offs between national food security, health of local communities, quantity and quality of water for other uses, disruption of biodiversity and other land related ecosystem services and the expansion of the sugar industry on the other hand [48]. To make way for commercial sugarcane plantation establishment, households lose their lands that had previously been used for food crop production, fuelwood provision, or livestock grazing. Although commercial sugarcane cultivation provides local jobs, they are mainly seasonal casual laborer jobs with little income for those involved. The casualization and seasonal employment with laborers being repeatedly hired on short-term (seasonally) absolve employers of the responsibility of providing benefits, such as pension contributions, health and social services, and employment security [48]. In the region, there is also a trade-off between commercial sugarcane benefits and the 
drawback (i.e., amount of atmospheric pollutants) that ensues from the off-cuts removal from the fields through burning [49-51].

The lack of enough food among the households calls for a significant increase in the productivity of subsistence agriculture to ensure long-term food security [28]. Yet, producing enough food for the growing population like in the study area, where soil fertility and many of the farmers lack the capacity to intensify agriculture, might require opening more land for cultivation. However, this is no-longer tenable, given that most of the land in the area is being taken up for commercial sugarcane cultivation that has an assured market ensuring income to the out-growers, seasonal casual labour employment to the unskilled local communities, and tax revenues to both the local and central governments.

\section{Conclusions}

Commercial sugarcane cultivation, although contributing to increased household income, does not necessarily increase food security among households in the Busoga sub-region, since even some of the households practicing commercial sugarcane cultivation were found to be food insecure. The fact that such households' practicing of commercial sugarcane cultivation compromises the ability to meet their own food needs places food security as a major consideration in commercial agricultural projects. These findings seem to support the conventional "wisdom" that the transition to commercial agriculture causes a deterioration in household-level food security. However, our results do not support the optimistic view that normally technology and commercialization stimulate agricultural growth, improve employment opportunities, and expand food supply-all central to the alleviation of poverty [9].

There is unsustainable expansion of sugarcane plantations in the study area, causing loss of traditional safety-nets (i.e., forest and wetland ecosystem services) and leaving many poor households without land for food crop cultivation and adequate livelihoods, making them more vulnerable to the future impacts of climate change. Hence, there are trade-offs between future expansions of sugarcane cultivation for economic benefits, and the quest for food security, water resources, environmental conservation, and provisioning of ecosystems goods and services. While acknowledging the serious environmental implications of sugarcane plantation expansion, and additionally the livelihood consequences of such impacts, future expansion is probably inevitable. If natural ecosystems in the study area were to be well managed, they could provide a wide range of local ecosystem services that reduce societies' vulnerability to climate change [52], thereby helping them to adapt both to current climate hazards and to future climate change [53]. Thus, it is important to put in place strategies that allow ecologically and socially sustainable sugarcane cultivation to maximize its development benefits, while minimizing the negative social and environmental impacts. It may be necessary to enact and enforce regulations for agro-ecological zoning and land use plans to ensure a balance between the competing commercial sugarcane and food crop cultivation. Governments should consider promoting distributional equity in areas where sugarcane is commercially grown through initiatives such as providing agricultural incentives from taxes generated from sugar companies to enhancing food production per unit area among the local communities. It will also be important for future studies to integrate the nexus between commercial sugarcane cultivation, natural resource governance, and other livelihood components of smallholder farmers to promote future sustainability.

Author Contributions: E.N.M., V.K.K., F.B. and D.W. conceptualized the original research idea, participated in data correction and analysis, and write-up of the draft manuscript. P.B., T.E. and M.S.M. actively participated in data correction and analysis, and write-up of the draft manuscript.

Acknowledgments: This study was funded in part by the Carnegie Corporation of New York and Makerere University, through the Next Generation of African Academics Project.

Conflicts of Interest: We the authors declare no conflict of interest. 


\section{References}

1. Vink, N. Commercializing agriculture in Africa: Economic, social and environmental impacts. Afr. J. Agric. Resour. Econ. 2013, 9, 1-17.

2. World Bank. Fact Sheet: The World Bank and Agriculture in Africa. 2013. Available online: http:/ / web.worldbank.org/WBSITE/EXTERNAL/COUNTRIES/AFRICAEXT/0, contentMDK: 21935583 pagePK:146736 piPK:146830 theSitePK:258644,00.html (accessed on 22 March 2013).

3. OECD/FAO. Agriculture in Sub-Saharan Africa: Prospects and Challenges for the Next Decade. In OECD-FAO Agricultural Outlook 2016-2025; OECD Publishing: Paris, France, 2016; pp. 59-95.

4. The WorldBank Group. Agriculture, Value Added (\% of GDP). Available online: https:/ / data.worldbank. org/indicator/NV.AGR.TOTL.ZS (accessed on 18 April 2018).

5. Binswanger, H.P.; von Braun, J. Technological change and commercialisation in agriculture: The effect on the poor. World Bank Res. Observ. 1991, 6, 57-80. [CrossRef]

6. Clay, J. Palm Oil. In World Agriculture and Environment: A Commodity-by-Commodity Guide to Impacts and Practices; Island Press: Washington, DC, USA, 2004; pp. 203-235.

7. Zen, Z.; Barlow, C.; Gondowarsito, R. Oil palm in Indonesian socio-economic improvement: A review of options. Oil Palm Ind. Econ. J. 2006, 6, 18-29.

8. Sheil, D.; Casson, A.; Meifaard, E.; van Nordwijk, M.; Gaskell, J.; Sunderland-Groves, J.; Wertz, K.; Kanninen, M. The Impacts and Opportunities of Oil Palm in South East Asia: What do We Know and What Do We Need to Know; Occasional Paper No. 51; CIFOR: Bogor, Indonesia, 2009.

9. Nesadurai, H.E.S. Food security, the palm oil-land conflict nexus, and sustainability: A governance role for a private multi-stakeholder regime like the RSPO? Pac. Rev. 2013, 26, 505-529. [CrossRef]

10. Koczberski, G.; Curry, G.N.; Bue, V. Oil palm, food security and adaptation among smallholder households in Papua New Guinea. Asia Pac. Viewp. 2012, 53, 288-299. [CrossRef]

11. Mwavu, E.N.; Witkowski, E.T.F. Land-use and cover changes around Budongo Forest Reserve, NW Uganda: Implications for sustainability of the forest/woodland. Land Degrad. Dev. 2010, 19, 606-622. [CrossRef]

12. Mwavu, E.N.; Ariango, E.; Ssegawa, P.; Kalema, V.N.; Bateganya, F.; Waiswa, D.; Byakagaba, P. Agrobiodiversity of homegardens in a commercial sugarcane cultivation land matrix in Uganda. Int. J. Biodivers. Sci. Ecosyst. Serv. Manag. 2016, 12, 191-201. [CrossRef]

13. FAO. State of Food Insecurity 2009; Food and Agriculture Organization: Rome, Italy, 2009.

14. Liverman, D.; Kapadia, K. Food systems and the global environment: An overview. In Food Security and Global Environmental Change; Ingram, J., Ericksen, P., Liverman, D., Eds.; Earthscan: Washington, DC, USA, 2010.

15. Kung'u, J.B. Food security in Africa: The challenges of researchers in the 21st century. In Advances in Integrated Soil Fertility Management in Sub-Saharan Africa: Challenges and Opportunities; Bationo, A., Boaz, W., Job, K., Joseph, K., Eds.; Springer: Dordrecht, The Netherlands, 2007; pp. 105-113.

16. Latham, M. Human Nutrition in the Developing World; FAO: Rome, Italy, 1997.

17. IFPRI (International Food Policy Research Institute). Reaching Sustainable Food Security for all by 2020. Getting the Priorities and Responsibilities Right; IFPRI: Washington, DC, USA, 2002.

18. Rosegrant, M.W.; Cline, S.A.; Li, W.; Valmonte-Santos, R. Looking Ahead: Long-Term Prospects for Africa's Agricultural Development and Food Security; IFPRI: Washington, DC, USA, 2005.

19. Kennedy, E.T. The Effects of Sugarcane Production on Food Security, Health, and Nutrition in Kenya: A Longitudinal Analysis; International Food Policy Research Institute: Washington, DC, USA, 1989; Volume 78.

20. Rist, L.; Feintrenie, L.; Levang, P. The livelihood impacts of oil palm: Smallholders in Indonesia. Biodivers. Conserv. 2010, 19, 1009-1024. [CrossRef]

21. Goldemberg, J.; Coelho, S.T.; Guardabassi, P. The sustainability of ethanol production from sugarcane. Energy Policy 2008, 36, 2086-2097. [CrossRef]

22. U.S. Agency for International Development's (USAID). Uganda Vulnerability to Climate Change Assessment Report; United States Agency for International Development: Washington, DC, USA, 2013.

23. Phillips, O.; Gentry, A.H. The useful plants of Tambopata, Peru: 1: Statistical hypothesis test with a new quantitative technique. Econ. Bot. 1993, 47, 15-32. [CrossRef]

24. SPSS Inc. Released 2008. SPSS Statistics for Windows, Version 17.0; SPSS Inc.: Chicago, IL, USA, 2008. 
25. Hagos, H.; Mengistu, L.; Mequanint, Y. Determining optimum harvest age of sugarcane varieties on the newly establishing Sugar Project in the tropical areas of Tendaho, Ethiopia. Adv. Crop Sci. Technol. 2014, 2, 156. [CrossRef]

26. U.S. Agency for International Development's (USAID). Policy Determination of 1992 for Definition of Food Security; United States Agency for International Development: Washington, DC, USA, 1992. Available online: http:/ / www.usaid.gov/policy/ads/200/pd19.pdf (accessed on 17 August 2017).

27. Food and Agriculture Organization (FAO). Declaration on World Food Security; World Food Summit; FAO: Rome, Italy, 1996.

28. Baiphethi, M.N.; Jacobs, P.T. The contribution of subsistence farming to food security in South Africa. Agrekon 2009, 48, 459-482. [CrossRef]

29. Quandt, S.A.; Arcury, T.A.; Early, J.; Tapia, J.; Davis, J.D. Household food security among migrant and seasonal Latino farmworkers in North Carolina. Public Health Rep. 2004, 119, 568-576. [CrossRef] [PubMed]

30. Quisumbing, A.R.; Brown, L.R.; Feldstein, H.S.; Haddad, L.; Penã, C. Women: The Key to Food Security; Food Policy Report; The International Food Policy Research Institute: Washington, DC, USA, 1995.

31. Verchot, L.V.; Van Noordwijk, M.; Kandji, S.; Tomich, T.; Ong, C.; Albrecht, A.; Mackensen, J.; Bantilan, C.; Anupama, K.V.; Palm, C. Climate change: Linking adaptation and mitigation through agroforestry. Mitig. Adapt. Strat. Glob. Chang. 2007, 12, 901-918. [CrossRef]

32. Howden, S.M.; Soussana, J.-F.; Tubiello, F.N.; Chhetri, N.; Dunlop, M.; Meinke, H. Adapting agriculture to climate change. Proc. Natl. Acad. Sci. USA 2007, 104, 19691-19696. [CrossRef] [PubMed]

33. Millennium Ecosystem Assessment (MEA). Ecosystems and Human Well-Being: Synthesis; Island Press: Washington, DC, USA, 2005.

34. Terry, A.; Ryder, M. Improving food security in Swaziland: the transition from subsistence to communally managed cash cropping. Nat. Resour. Forum 2007, 31, 263-272. [CrossRef]

35. Thrupp, L.A. Linking agricultural biodiversity and food security: The valuable role of agrobiodiversity for sustainable agriculture. Int. Aff. 2000, 76, 265-281. [CrossRef] [PubMed]

36. Sunderland, T.C.H. Food security: Why is biodiversity important? Int. For. Rev. 2011, 13, 265-274. [CrossRef]

37. Maitima, J.M.; Gumbo, D.J. Land Use in Sub-Saharan Africa. In Global Change Processes and Impact in Africa: A Synthesis; Otter, L., Olago, D.O., Niang, L., Eds.; East African Educational Publishers: Nairoib, Kenya, 2007; pp. 109-130. Available online: https:/ / cgspace.cgiar.org/bitstream/handle/10568/3016/Land\%20\%20Use\% 20Chapter\%20Proofs\%20pd.pdf?sequence=1\&isAllowed $=y$ (accessed on 20 February 2018).

38. Jarvis, A.; Lau, C.; Cook, S.; Wollenberg, E.; Hansen, J.; Bonilla, O.; Challinor, A. An integrated adaptation and mitigation framework for developing agricultural research: Synergies and trade-offs. Exp. Agric. 2011, 47, 185-203. [CrossRef]

39. Adger, N. Vulnerability. Glob. Environ. Chang. 2006, 16, 268-281. [CrossRef]

40. Locatelli, B.; Evans, V.; Wardell, A.; Andrade, A.; Vignola, R. Forests and climate change in Latin America: Linking adaptation and mitigation. Forests 2011, 2, 431-450. [CrossRef]

41. Belcher, B.M. Forest product markets, forests and poverty alleviation. Int. For. Rev. 2005, 7, 82-89.

42. Nkem, J.; Kalame, F.B.; Idinoba, M.; Somorin, O.A.; Ndoye, O.; Awono, A. Shaping forest safety nets with markets: Adaptation to climate change under changing roles of tropical forests in Congo Basin. Environ. Sci. Policy 2010, 13, 498-508. [CrossRef]

43. Uganda Bureau of Statistics (UBOS). Uganda National Household Survey 2016/17; UBOS: Kampala, Uganda, 2007.

44. Wheeler, T.; von Braun, J. Climate change impacts on global food security. Science 2013, 341, 508-513. [CrossRef] [PubMed]

45. Sparovek, G.; Barretto, A.; Berndes, G.; Martins, S.; Maule, R. Environmental, land-use and economic implications of Brazilian sugarcane expansion 1996-2006. Mitig. Adapt. Strateg. Glob. Chang. 2009, 14, 285-298. [CrossRef]

46. Immink, M.D.C.; Alarcon, J.A. Household income, food availability, and commercial crop production by smallholder farmers in western highlands of Guatemala. Econ. Dev. Cult. Chang. 1996, 41, 319-342.

47. Kennedy, E.; Cogill, B. The commercialization of agriculture and household-level food security: The case of southwestern Kenya. World Dev. 1988, 16, 1075-1081. [CrossRef] 
48. Hess, T.M.; Sumberg, J.; Biggs, T.; Georgescu, M.; Haro-Monteagudo, D.; Jewitt, G.; Ozdogan, M.; Marshall, M.; Thenkabail, P.; Daccache, A.; et al. A sweet deal? Sugarcane, water and agricultural transformation in Sub-Saharan Africa. Glob. Environ. Chang. 2016, 39, 181-194. [CrossRef]

49. Hassuani, S.J.; Leal, MR.; de Carvalho Macedo, I. Biomass Power Generation, Sugarcane Bagasse and Trash, 1st ed.; Report PNUD-Programa das Nações Undas Para O Desenvolvimento CTC-Centro de Technologia Canavieira: Piracreaba, Brazil, 2005.

50. Pankhurst, C. Should Sugarcane Trash be Used as Biofuel for Cogeneration of Left in the Field for its Long-Term Benefits to the Soil Health and Crop Productivity; A Report Prepared for the Sugar Yield Decline Venture; Sugar Research \& Development Corporation (SRDC): Queensland, Australia, 2005.

51. Watson, H.K.; Garland, G.G.; Purchase, B.; Dercas, N.; Griffee, P.; Johnson, F.X. Bioenergy for Sustainable Development and Global Competitiveness: The Case of Sugar Cane in Southern Africa, Thematic Report 1-Agriculture; CARENSA/SEI Special Report Series; SEI: Stockholm, Sweden, 2008.

52. Vignola, R.; Locatelli, B.; Martinez, C.; Imbach, P. Ecosystem-based adaptation to climate change: What role for policy-makers, society and scientists? Mitigat. Adapt. Strat. Glob. Chang. 2009, 14, 691-696. [CrossRef]

53. Turner, W.R.; Oppenheimer, M.; Wilcove, D.S. A force to fight global warming. Nature 2009, 428, $278-279$. [CrossRef] [PubMed]

(C) 2018 by the authors. Licensee MDPI, Basel, Switzerland. This article is an open access article distributed under the terms and conditions of the Creative Commons Attribution (CC BY) license (http://creativecommons.org/licenses/by/4.0/). 